\title{
Epidemiology and aetiology of acute non-tuberculous salpingitis. A comparison between the early 1970s and the early 1980 s with special reference to gonorrhoea and use of intrauterine contraceptive device
}

Francis Kamwendo, Lars Forslin, Dan Danielsson

\begin{abstract}
More patients were hospitalised for acute salpingitis at the Department of Obstetrics and Gynaecology, Örebro Medical Centre, Örebro, Sweden, during the 5 year period 1970-1974 (period I) as compared with that of 1980-1984 (period II), 666 patients and 524 respectively, a decrease of $22 \%$. The majority of cases, $92 \%$ in period $I$ and $85 \%$ in period $I I$, occurred among women 15-34 years of age, that is a relative increase of patients aged over 34 from $8 \%$ in period I to $15 \%$ in period II. Concomitant urogenital gonorrhoea occurred in $26.2 \%$ of the patients in period I compared with $12.0 \%$ in period II, a highly significant decrease ( $p<0.001)$ mainly confined to the age group 15-24, whereas there was no relative difference for the two periods in the age group 25-34 years. The number of patients using intrauterine contraceptive device (IUCD) was $96 / 666(14.4 \%)$ in period I compared with 113 / $524(21.6 \%)$ in period II $(p<0.001)$. There were also relatively more IUCD users among the patients with gonorrhoea and acute salpingitis in period II (15.5\%) compared with period I $(10 \cdot 4 \%)$ but this difference was not statistically significant. From 1981 to $1984370 / 424$ patients were cultured for Chlamydia trachomatis and $27 \cdot 8 \%(103 / 370)$ were positive. Thus Chlamydia trachomatis is at present, at least in the Örebro area, the most frequently isolated STD agent among acute salpingitis patients while gonorrhoea is of much less importance.
\end{abstract}

Department of Obstetrics and Gynaecology, Orebro Medical Centre, S-701 85 Orebro, Sweden

Francis Kamwendo, Lars Forslin

Department of Clinical Microbiology and Immuno-

logy, Örebro Medical Centre, S-701 85 Örebro, Sweden

Dan Danielsson
Acute salpingitis is a serious disease affecting women predominantly in the ages of 15 to 25 years with a high risk of infertility, ectopic pregnancy and chronic lower abdominal pain..$^{1-3}$ It is generally considered that about $99 \%$ of the cases of non-tuberculous acute salpingitis are caused by intracanalicular spread of microbial pathogens from a lower genital tract infection which is associated in the majority of cases with sexually transmitted diseases.

Urogenital gonorrhoea has been known for a long time to be a common cause of acute salpingitis. In several European studies from the late 1950 s to the early 1970s gonorrhoea was reported to occur from $17 \%-44 \%$ in women with acute salpingitis. ${ }^{1-5}$ Gonorrhoea in patients with acute salpingitis was also reported to be high in $\mathrm{USA}^{67}$ as well as in other parts of the world. ${ }^{89}$

In a 5 year study 1970-1974 from an urban area of Sweden, Forslin et $a l^{10}$ demonstrated a significant decrease of the incidence of urogenital gonorrhoea from $43 \%$ to $16 \%$ in patients with acute salpingitis. This decrease coincided with the decrease of gonorrhoea in Sweden which started in the early 70s and has continued during the 80 s (fig 1a).

However, the yearly number of patients admitted to our hospital with acute salpingitis in the period of 1970-1974 did not decrease but remained high. Ten years later during the 5 year period 1980-1984 we have found from our medical records that the number of patients hospitalised for acute salpingitis decreased. The reasons for this are unclear but genital infections other than gonorrhoea and the type of contraceptives used might be of importance.

In the present work we analysed the role of urogenital gonorrhoea in various age groups of patients hospitalised for acute salpingitis during the two five-year periods, 1970-1974 and 1980-1984. The influence of the use of intrauterine contraceptive device was analysed and the incidence of genital C. trachomatis infections was studied during 1981-1984. 
GONORRHOEA 1966 - 1985

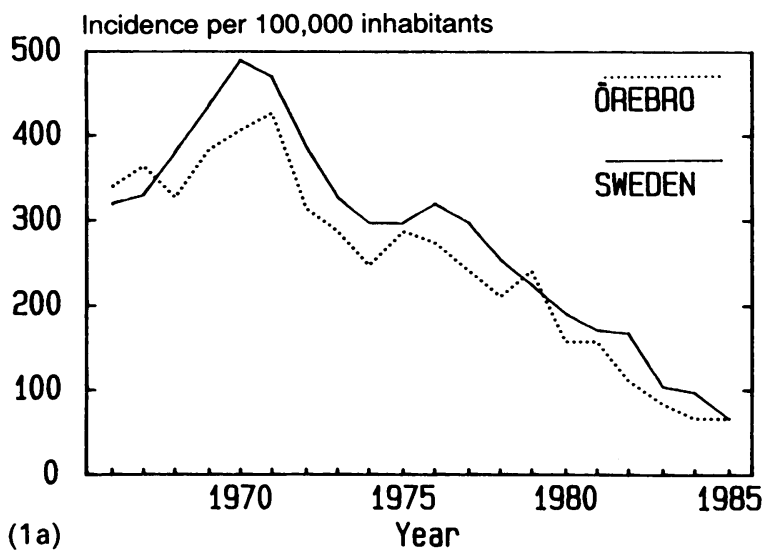

GONORRHOEA IN WOMEN 1966 - 1985

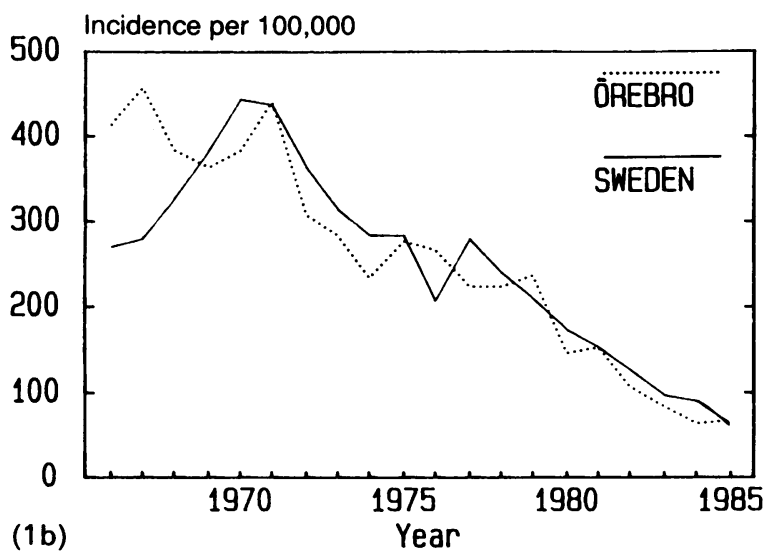

Fig 1 The yearly incidence of gonorrhoea per 100,000 population in Sweden and Orebro county during 1966-1985. a) Total incidence, b) Incidence in women.

\section{Materials and methods}

Patients, diagnostic criteria and demographic data

The study comprised 1,190 inpatients at the Department of Gynaecology, Örebro Medical Centre, Örebro, Sweden in whom acute salpingitis had been diagnosed (see below) in the periods 19701974 and 1980-1984. The patients cared for in the period of 1970-1974, in all 666, have been described previously. ${ }^{10}$ The same clinical procedures were followed during the latter period and thus all patients attending the hospital with suspected acute salpingitis were routinely hospitalised. Diagnosis was based on the following criteria: history of low abdominal pain with palpable adnexal mass or tenderness and at least two of the following signs and symptoms; vaginal discharge, menstrual irregularity, dysuria, temperature above $38^{\circ} \mathrm{C}$ and an erytrocyte sedimentation rate (ESR) $>15 \mathrm{~mm} / 1$ st hour. Physical examination was repeated and the clinical signs and symptoms were judged by a senior physician the morning following admission. In the period 1970-74 acute salpingitis was confirmed in 427 patients $(64 \cdot 1 \%)$ by laparoscopy, using the criteria of Jacobson and Weström; ${ }^{11}$ in 239 patients $(35.9 \%)$ the diagnosis was based on clinical and physical findings. The corresponding figures for the period 1980-1984 were $318(60 \cdot 7 \%)$ and 206 $(39 \cdot 3 \%)$, respectively.

\section{Bacteriology}

Within $24 \mathrm{~h}$ of patient's admission to hospital specimens for culture of Neisseria gonorrhoeae were taken from the urethra, cervical os, and rectal mucosa with a charcoal-treated cotton swab and transported to the laboratory in modified Stuart's transport medium. ${ }^{12}$ On arrival at the laboratory the specimens were cultured on selective and non-selective gonococcal media for the detection and identification of $\mathrm{Ngonorrhoeae}$ as earlier described. ${ }^{13}$

Culture diagnosis of genital $C$. trachomatis infection was started on a routine basis at our hospital in June 1980 and data for the last four years of the latter study period were included. Specimens were collected from the urethra and cervical os using a cottontipped aluminum wire (ENT, Medical Wire \& Equipment, UK). Transport of specimens, culture and identification of inclusion bodies were carried out as described elsewhere. ${ }^{14}$ Specimens for C. trachomatis were taken before the gonococcal specimens.

\section{Statistical analysis}

The Chi square test was used to compare frequencies. The following terms were used: $p<0.001$, difference highly significant; $0.001<\mathrm{p}<0.01$, difference significant; $0.01<0.05$, difference almost significant.

\section{Results}

Acute salpingitis and incidence of gonorrhoea

Table I shows that the yearly number of patients hospitalised for acute salpingitis at our Department of Gynaecology was relatively constant during the period of 1980-1984 with a mean of 105 per year (range 97-113) whereas there were larger fluctuations (range 111-177) during the period of 19701974 with a mean of 133 per year. It can also be seen that the percentage of patients with gonorrhoea was more than twice as high in the first period as compared with the second $(26.2 \%$ versus $12 \%)$. The difference was highly significant $(p<0.001)$. There was a steady decline within both periods, from $44.6 \%$ to $17.4 \%$ in the period of $1970-1974$ and from $19.8 \%$ 
Table 1 The yearly incidence of urogenital gonorrhoea in patients with acute salpingitis. A comparison between the five-year periods of 1980-1984 and 1970-1974

\begin{tabular}{|c|c|c|c|c|c|c|c|}
\hline \multicolumn{4}{|c|}{ Period 1980-1984 } & \multicolumn{4}{|c|}{ Period 1970-1974 } \\
\hline \multirow[b]{2}{*}{ Year } & \multicolumn{3}{|c|}{ No of patients with acute salpingitis } & \multirow[b]{2}{*}{ Year } & \multicolumn{3}{|c|}{ No of patients with acute salpingitis } \\
\hline & $\begin{array}{l}\text { Confirmed by } \\
\text { laparoscopy }\end{array}$ & $\begin{array}{l}\text { Clinical diagnosis; } \\
\text { laparoscopy not } \\
\text { performed }\end{array}$ & Total & & $\begin{array}{l}\text { Confirmed by } \\
\text { laparoscopy }\end{array}$ & $\begin{array}{l}\text { Clinical diagnosis; } \\
\text { laparoscopy not } \\
\text { performed }\end{array}$ & Total \\
\hline & * & * & 太 & & $\star$ & * & * \\
\hline $\begin{array}{l}1980 \\
1981 \\
1982 \\
1983 \\
1984\end{array}$ & $\begin{array}{l}47(7 / 41 ; 17 \cdot 1) \\
54(7 / 51 ; 13 \cdot 7) \\
57(8 / 51 ; 15 \cdot 7) \\
74(3 / 67 ; 4 \cdot 5) \\
86(4 / 79 ; 5 \cdot 1)\end{array}$ & $\begin{array}{l}53(10 / 45 ; 22 \cdot 2) \\
55(6 / 53 ; 11 \cdot 3) \\
40(7 / 38 ; 18 \cdot 4) \\
31(5 / 31 ; 16 \cdot 1) \\
27(1 / 26 ; 3 \cdot 8)\end{array}$ & $\begin{array}{c}100(17 / 86 ; 19 \cdot 8) \\
109(13 / 104 ; 12 \cdot 5) \\
97(15 / 89 ; 16 \cdot 9) \\
105(8 / 98 ; 8 \cdot 2) \\
113(5 / 105 ; 4 \cdot 8)\end{array}$ & $\begin{array}{l}1970 \\
1971 \\
1972 \\
1973 \\
1974\end{array}$ & $\begin{array}{c}67(29 / 63 ; 46 \cdot 0) \\
107(27 / 96 ; 28 \cdot 1) \\
66(14 / 64 ; 21 \cdot 9) \\
79(12 / 79 ; 15 \cdot 2) \\
108(12 / 107 ; 11 \cdot 2)\end{array}$ & $\begin{array}{l}59(25 / 58 ; 43 \cdot 1) \\
32(11 / 15 ; 73 \cdot 3) \\
45(10 / 44 ; 22 \cdot 7) \\
34(6 / 34 ; 17 \cdot 6) \\
69(18 / 65 ; 27 \cdot 7)\end{array}$ & $\begin{array}{l}126(54 / 121 ; 44 \cdot 6) \\
139(38 / 111 ; 34 \cdot 2) \\
111(24 / 108 ; 22 \cdot 2) \\
113(18 / 113 ; 15 \cdot 9) \\
177(30 / 172 ; 17 \cdot 4)\end{array}$ \\
\hline Total & $318(29 / 289 ; 10.0)$ & $206(29 / 193 ; 15.0)$ & $524(58 / 482 ; 12 \cdot 0)$ & & $427(94 / 409 ; 23.0)$ & $239(70 / 216 ; 32 \cdot 4)$ & $666(164 / 625 ; 26 \cdot 2)$ \\
\hline
\end{tabular}

^Figures within brackets: No of patients with gonorrhoea/No of patients from whom anogenital specimens were cultured for $N$ gonorrhoeae; $(\%)$.

Table 2 Comparison of the age distribution of patients with acute salpingitis and gonorrhoea during the five-year periods of 1980-1984 and 1970-1974

\begin{tabular}{|c|c|c|c|c|c|c|c|c|c|}
\hline \multicolumn{5}{|c|}{ Period 1980-1984 } & \multicolumn{5}{|c|}{ Period 1970-1974 } \\
\hline \multirow[b]{2}{*}{$\begin{array}{l}\text { Age } \\
\text { group }\end{array}$} & \multirow[b]{2}{*}{$\begin{array}{l}\% \text { of } \\
\text { total }\end{array}$} & \multicolumn{3}{|c|}{ No of patients with acute salpingitis and gonorrhoea } & \multirow[b]{2}{*}{$\begin{array}{l}\text { Age } \\
\text { group }\end{array}$} & \multirow[b]{2}{*}{$\begin{array}{l}\% \text { of } \\
\text { total }\end{array}$} & \multicolumn{3}{|c|}{ No of patients with acute salpingitis and gonorrhoea } \\
\hline & & $\begin{array}{l}\text { Confirmed by } \\
\text { laparoscopy }\end{array}$ & $\begin{array}{l}\text { Clinical } \\
\text { diagnosis } \dagger\end{array}$ & Total & & & $\begin{array}{l}\text { Confirmed by } \\
\text { laparoscopy }\end{array}$ & $\begin{array}{l}\text { Clinical } \\
\text { diagnosis } \dagger\end{array}$ & Total \\
\hline & & $\star$ & $\star$ & $\star$ & & & $\star$ & $\star$ & $\star$ \\
\hline $\begin{array}{l}<15 \\
15-24 \\
25-34 \\
>34\end{array}$ & $\begin{array}{r}0.9 \\
52.3 \\
31.5 \\
15.3\end{array}$ & $\begin{array}{c}2 / 4(50) \\
15 / 164(9 \cdot 1) \\
8 / 99(8 \cdot 1) \\
4 / 5(7 \cdot 8)\end{array}$ & $\begin{array}{l}0 / 1(0) \\
14 / 110(12 \cdot 7) \\
12 / 66(18 \cdot 2) \\
3 / 29(10 \cdot 3)\end{array}$ & $\begin{array}{c}2 / 5(40) \\
29 / 274(10 \cdot 6) \\
20 / 165(12 \cdot 1) \\
7 / 80(8 \cdot 6)\end{array}$ & $\begin{array}{l}<15 \\
15-24 \\
25-34 \\
>34\end{array}$ & $\begin{array}{r}0 \cdot 9 \\
60 \cdot 1 \\
31 \cdot 1 \\
8 \cdot 4\end{array}$ & $\begin{array}{c}1 / 4(25) \\
57 / 243(23.5) \\
27 / 136(19.9) \\
7 / 44(15.9)\end{array}$ & $\begin{array}{l}0 / 2(0) \\
50 / 157(31 \cdot 8) \\
22 / 68(32 \cdot 4) \\
1 / 12(8 \cdot 3)\end{array}$ & $\begin{array}{c}1 / 6(16 \cdot 7) \\
106 / 400(26 \cdot 8) \\
49 / 204(24 \cdot 0) \\
8 / 56(14 \cdot 3)\end{array}$ \\
\hline Total & & $29 / 318(9 \cdot 1)$ & $29 / 206(14 \cdot 1)$ & $58 / 524(12 \cdot 0)$ & & & $92 / 427(21 \cdot 5)$ & $73 / 239(30 \cdot 0)$ & $164 / 666(24 \cdot 6)$ \\
\hline
\end{tabular}

†Laparoscopy not performed.

$\star$ No of patients with gonorrhoea/No of patients with acute salpingitis $(\%)$.

Table 3 Patients of different age groups with acute salpingitis (AS) using intrauterine contraceptive device (IUCD) and infected with $N$ gonorrhoeae. Comparison between the five-year periods 1980-1984 and 1970-1974

\begin{tabular}{|c|c|c|c|c|c|c|c|}
\hline Period & $1980-1984$ & & & \multicolumn{4}{|c|}{ Period 1970-1974 } \\
\hline $\begin{array}{l}\text { Age } \\
\text { group }\end{array}$ & $\begin{array}{l}\text { Confirmed by } \\
\text { laparoscopy }\end{array}$ & $\begin{array}{l}\text { Clinical } \\
\text { diagnosis } \dagger\end{array}$ & Total & $\begin{array}{l}\text { Age } \\
\text { group }\end{array}$ & $\begin{array}{l}\text { Confirmed by } \\
\text { laparoscopy }\end{array}$ & $\begin{array}{l}\text { Clinical } \\
\text { diagnosist }\end{array}$ & Total \\
\hline $\begin{array}{l}<15 \\
15-24 \\
25-34 \\
>34\end{array}$ & $\begin{array}{l}0 / 4(0)^{\star} \\
17 / 164 ; 10 \cdot 4(0) \\
31 / 99 ; 31 \cdot 3(25) \\
18 / 51 ; 35 \cdot 3(25)\end{array}$ & $\begin{array}{l}0 / 1(0) \star \\
10 / 110 ; 9 \cdot 1(4 \cdot 3) \\
23 / 66 ; 34 \cdot 8(25) \\
14 / 29 ; 48 \cdot 3(33 \cdot 3)\end{array}$ & $\begin{array}{c}0 / 5(0)^{\star} \\
27 / 274 ; 9 \cdot 9(6.9) \\
54 / 165 ; 32 \cdot 7(25) \\
32 / 80 ; 40(28 \cdot 6)\end{array}$ & $\begin{array}{l}<15 \\
15-24 \\
25-34 \\
>34\end{array}$ & $\begin{array}{l}0 / 4(0)^{\star} \\
32 / 243 ; 13 \cdot 2(3 \cdot 5) \\
22 / 136 ; 16 \cdot 2(14 \cdot 8) \\
2 / 44 ; 4 \cdot 5(0)\end{array}$ & $\begin{array}{l}0 / 2(0)^{\star} \\
22 / 157 ; 14 \cdot 0(12) \\
17 / 68 ; 25 \cdot 0(22 \cdot 7) \\
1 / 12 ; 8 \cdot 3(0)\end{array}$ & $\begin{array}{l}0 / 6(0) \star \\
54 / 400 ; 13.5(7.5) \\
39 / 204 ; 19.1(18.4) \\
3 / 56 ; 5.4(0)\end{array}$ \\
\hline
\end{tabular}

„Figures within brackets: percent gonorrhoea in patients with IUCD.

$\dagger$ Laparoscopy not performed.

to $4.8 \%$ in the period of $1980-1984$. The difference was highly significant $(p<0.001)$ between the first three years and the last two years of each period.

Table 1 shows that the yearly gonorrhoea frequency was very similar for the patients with a clinical diagnosis of acute salpingitis and for those in whom the diagnosis was confirmed by laparoscopy.
There were however, a few exceptions. In 1971, 1974 and 1983 the frequency was higher in the groups of patients with a clinical diagnosis. This will be further commented on in the Discussion.

The reported number of gonorrhoea per 100,000 inhabitants (men and women, respectively) in the whole of Sweden and in our area is shown in fig 1a. It 
Table 4 The incidence of urogenital $C$ trachomatis $(C t)$ infection in patients with acute salpingitis (AS) 1981-1984. Data for Ct cultures not complete for 1980 (see methods)

\begin{tabular}{llcc}
\hline \multicolumn{4}{c}{ No of patients with $A S$ and Ct infection } \\
\cline { 2 - 4 } Year & $\begin{array}{l}\text { Confirmed by } \\
\text { laparoscopy }\end{array}$ & $\begin{array}{l}\text { Clinical diagnosis } \\
\text { Laparoscopy not } \\
\text { performed }\end{array}$ & Total \\
\hline & $\dagger \star \star$ & $\dagger$ & $\dagger$ \\
1981 & $54 ; 14 / 51(27 \cdot 5)$ & $55 ; 16 / 34(47 \cdot 1)$ & $109 ; 30 / 85(35 \cdot 3)$ \\
1982 & $57 ; 13 / 48(27 \cdot 1)$ & $40 ; 13 / 37(35 \cdot 1)$ & $97 ; 26 / 85(30 \cdot 6)$ \\
1983 & $74 ; 13 / 64(20 \cdot 3)$ & $31 ; 12 / 33(36 \cdot 4)$ & $105 ; 25 / 97(25 \cdot 8)$ \\
1984 & $86 ; 19 / 77(24 \cdot 7)$ & $27 ; 3 / 26(11 \cdot 5)$ & $113 ; 22 / 103(21 \cdot 4)$ \\
Total & $271 ; 59 / 240(24 \cdot 6)$ & $153 ; 44 / 130(33 \cdot 8)$ & $424 ; 103 / 370(27 \cdot 8)$ \\
\hline
\end{tabular}

^No of patients with acute salpingitis.

+ No of patients positive for $C$ trachomatis/No of patients from whom urogenital specimens were cultured ( $\%$ positive).

can be seen that the incidence patterns are fairly similar. There was a slight increase in 1974-1976 which might explain the higher number of patients with gonococcal salpingitis in 1974.

Age distribution of patients with acute salpingitis and with gonorrhoea

Table 2 shows the age distribution of patients with acute salpingitis and gonorrhoea during the 5 year periods of 1980-1984 and 1970-1974. For both periods the number of patients aged below 15 years was very low and the percentages were nearly identical for the age group 25-34. It can be noted, however, that the total number of patients $(400$ versus 274) as well as the relative percentage (60.1 versus 52.3) was higher in the age group 15-24 in the period of 1970-1974 compared with that of 1980 1984. The reverse was found for women aged over 34 , that is, the total number of patients as well as the relative percentage was higher for the period of 1980-1984 compared with that of 1970-1974.

As can be seen in table 2 the relative percentage of patients with acute salpingitis and gonorrhoea in $1970-1974$ was $26 \cdot 8 \%(107 / 400)$ and $24.0 \%(49 / 204)$ for the age groups $15-24$ and 25-34, respectively, whereas the corresponding figures in 1980-1984 were $10 \cdot 6 \%(29 / 274)$ and $12 \cdot 1 \%(20 / 165)$. The differences were highly significant $(p<0.001)$.
Though the relative percentage of patients with acute salpingitis and gonorrhoea was lower in the age group $>34$ in 1980-1984 compared with 1970-1974 the total number of patients with gonorrhoea was nearly equal in this age group for the two 5 year periods. The figures are relatively small but indicate an increase of the total number of patients in the age group $>34$ with acute salpingitis for the period of 1980-1984. Compared with the other age groups there is also a relative increase of those with gonorrhoea.

Usage of intrauterine contraceptive device in different age groups of patients with acute salpingitis and gonorrhoea

In the period of $1980-198421.6 \%$ of the patients with acute salpingitis used IUCD as contraceptive compared with $14.4 \%$ of the patients in the period of 1970-1974 (table 3). It can also be seen that for the period of $1980-198415 \cdot 5 \%(9 / 58)$ of the patients with gonorrhoea were using IUCD compared with $10.4 \%(17 / 164)$ for the period of 1970-1974. The greatest differences were found in the age groups $25-34$ and $>34$.

Genital C. trachomatis infections in patients with acute salpingitis in 1981-1984 and the use of IUCD

Table 4 shows the number of patients from whom cultured urogenital specimens were positive for $C$. trachomatis infection. In all, urogenital specimens were cultured from 370 out of $424(87.2 \%)$ and $103 /$ $370(27 \cdot 8 \%$ ) were positive (range: $21 \cdot 4-35 \cdot 3 \%$ ). The incidence was highest in 1981 and lowest in 1984. The difference between 1981 and 1984 is almost significant $(p<0.05)$.

Table 5 shows the age distribution of the number of patients with IUCD and acute salpingitis infected with $C$. trachomatis. In all $15 / 103(14.6 \%)$ of the patients had this combination, and though the figures are small this combination occurred more often in the higher age groups. The figures and the age distribution pattern are very similar to those of IUCD users with acute salpingitis and gonorrhoea (table 3 ). There were only two among the 19 IUCD users patients infected with both $C$. trachomatis and $N$. gonorrhoeae.

Table 5 Patients of different age groups in 1981-1984 with acute salpingitis ( $A S$ ) using intrauterine contraceptive device (IUCD) and with genital C trachomatis (Ct) infection or Ct and $\mathrm{N}$ gonorrhoeae $(\mathrm{Ng}$ ) infection

\begin{tabular}{|c|c|c|c|c|c|c|}
\hline \multirow[b]{2}{*}{$\begin{array}{l}\text { Age } \\
\text { group }\end{array}$} & \multicolumn{3}{|c|}{ No of patients with Ct infection/IUCD users with $A S(\%)$} & \multicolumn{3}{|c|}{ No of patients with Ct and $\mathrm{Ng}$ infection/IUCD users with $A S(\%)$} \\
\hline & $\begin{array}{l}\text { Confirmed by } \\
\text { laparoscopy }\end{array}$ & $\begin{array}{l}\text { Clinical } \\
\text { diagnosis* }\end{array}$ & Total & $\begin{array}{l}\text { Confirmed by } \\
\text { laparoscopy }\end{array}$ & $\begin{array}{l}\text { Clinical } \\
\text { diagnosis }\end{array}$ & Total \\
\hline $\begin{array}{l}<15 \\
15-24 \\
25-34 \\
>34\end{array}$ & $\begin{array}{l}0 / 1 \\
6 / 44(13 \cdot 6) \\
3 / 12(25) \\
2 / 3(66 \cdot 7)\end{array}$ & $\begin{array}{l}0 / 0 \\
2 / 33(6 \cdot 1) \\
2 / 8(25) \\
0 / 2(0)\end{array}$ & $\begin{array}{l}0 / 1 \\
8 / 77(10 \cdot 4) \\
5 / 20(25) \\
2 / 5(40 \cdot 0)\end{array}$ & $\begin{array}{l}0 / 1 \\
0 / 10 \\
0 / 1 \\
1 / 1\end{array}$ & $\begin{array}{l}0 / 0 \\
0 / 5 \\
1 / 1 \\
0 / 0\end{array}$ & $\begin{array}{l}0 / 1 \\
0 / 15 \\
1 / 2 \\
1 / 1\end{array}$ \\
\hline Total & $11 / 60(18 \cdot 3)$ & $4 / 43(9 \cdot 3)$ & $15 / 103(14 \cdot 6)$ & $1 / 13(7 \cdot 6)$ & $1 / 6(16 \cdot 6)$ & $2 / 19(10 \cdot 5)$ \\
\hline
\end{tabular}

^Laparoscopy not performed. 


\section{Discussion}

This investigation showed that more women were hospitalised for acute salpingitis in the early 1970 s than in the early 1980s (during the corresponding 5 year periods, 666 versus 524, which is a decrease of nearly $22 \%$ ) at the Department of Obstetrics and Gynaecology, Örebro Medical Centre, Örebro, Sweden which serves an urban and rural area of approximately 120,000 inhabitants. If 1974 is compared with 1984 the decrease would be as much as $36 \%$ which shows that comparisons must be done over longer periods of time.

The occurrence of gonorrhoea in patients with acute salpingitis decreased from 54/126 (45\%) in 1970 to $30 / 172(17 \%)$ in 1974 , a factor of 2.5 . This trend continued in the early 1980 s with even a greater decrease from $17 / 86(20 \%)$ in 1980 to $5 / 105(5 \%)$ in 1984 , a factor of 4 . The average incidence of urogenital gonorrhoea in acute salpingitis patients was $26.2 \%$ in $1970-1974$ but only half as much $(12.0 \%)$ in $1980-1984$, a highly significant difference $(p<0.001)$. This decrease follows that of urogenital gonorrhoea in women in the district of Örebro as in the whole of Sweden (fig 1b).

It has become a tradition in Sweden and some other countries to confirm by laparoscopy a clinical diagnosis of acute salpingitis. ${ }^{115-18}$ All patients are not, however, subjected to laparoscopy. This may be due to shortness of resources, the patient is clinically too ill, or to the fact that the clinical findings, symptoms and signs are very characteristic for acute salpingitis. In the present study diagnosis of acute salpingitis was clinically based, that is, without laparoscopy, in $35.8 \%$ of the patients in the period $1970-1974$, and in $39.3 \%$ of the patients in 1980 1984. It is clinical experience that acute salpingitis patients with gonorrhoea are often more ill than those without. ${ }^{115}$ This might have been a contributing factor and might also explain that relatively high percentages of patients with a clinical diagnosis of acute salpingitis and gonorrhoea were not subjected to laparoscopy in 1971, 1974 and 1983.

During both periods it was mostly women in the age group 15-34 years who were hospitalised for acute salpingitis, a finding that agrees with that of other investigators. ${ }^{12419}$ In the period of $1980-1984$ $15 \%$ of the patients were $>34$ years of age as compared to $8 \%$ in the period of $1970-1974$. A tendency to a shift to higher age groups was also reported by Forslin et al..$^{10}$

During the time period studied reported gonorrhoea in the age groups 15-34 decreased in the district of Örebro from $1,575 / 100,000$ in 1970 to $790 /$ 100,000 in 1974, a factor of 2 and from $495 / 100,000$ in 1980 to $210 / 100,000$ in 1984 , a factor of $2 \cdot 4$. Corresponding figures for the whole of Sweden were 1,471 / 100,000 in 1970 and $920 / 100,000$ in 1974 , a factor of $1 \cdot 6 ; 537 / 100,000$ in 1980 and $258 / 100,000$ in 1984 , a factor of 2. The situation in our district was thus similar to that in Sweden generally. The figs 1a and $1 \mathrm{~b}$ also show that the decrease of the incidence of acute salpingitis with gonorrhoea was even greater than the decrease of reported urogenital gonorrhoea. At least in Sweden gonorrhoea is at present of minor importance in the aetiology of acute salpingitis.

IUCD has been shown to be a risk factor for acute salpingitis and pelvic inflammatory disease. ${ }^{60-23}$ In the present study $21.6 \%$ of the patients in $1980-1984$ were IUCD users compared with $14.4 \%$ in 1970 1974. This difference is highly significant ( $p$ $=<0.001)$. For the age group $>34$ years there were both totally and relatively more IUCD users among the patients in 1980-1984 than in 1970-1974 (table 3 ). This increase of acute salpingitis among IUCD users might reflect an increased use of this type of contraceptives by women in Sweden. Data supporting this are not available but Swedish gynaecologists have changed their policy as to whom IUCD should be prescribed. The only available statistics on contraceptive methods used in Sweden by women between the ages of 20-44 years were published in May 1982 based on an interview a year before. A total of $62.2 \%$ of the women used some sort of contraception and of these $27 \%$ used IUCD. Since the late 1970 s this type of contraceptive method is very seldom recommended for young nulliparous women in Sweden..$^{24}$ This could explain the increase in the age group $>34$ years, which is highly significant $(p<$ $0.001)$.

Copper coated IUCDs were officially included on the pharmaceutical register by the National Board of Health and Welfare in the middle of the 1970s while the same body stopped the importation of noncopper coated IUCDs in 1981 . Very few-about 10 per year-of the Lippes Loop tÿpe are still imported privately on special licence for those women who started using them 15-20 years ago and prefer to continue with the same type. ${ }^{25}$

It has been suggested that copper coated IUCD, the type almost exclusively used in Sweden at present, might protect against specific infections with $N$ gonorrhoeae and $C$ trachomatis. ${ }^{26}$ Our study does not confirm this since there were relatively more patients with IUCD and gonorrhoea in 1980-1984 than in $1970-1974(9 / 58=15.5 \%$ and $17 / 164=$ $10.4 \%$ respectively). The difference is not significant, however, $(p=0 \cdot 294)$.

According to several Swedish investigators, $C$ trachomatis is the main sexually transmitted microbe causing salpingitis in this country at present. ${ }^{16-1827}$ Our study confirms this. The average incidence of $C$ trachomatis was higher than that for $N$ gonorrhoeae for the period of $1981-1984,27 \cdot 8 \%$ versus $12.0 \%$, (tables 1 and 4). However, the number of patients with chlamydia infection and acute salpingitis decreased during this period from $30 / 85(35 \cdot 3 \%)$ in 
1981 to $22 / 103(21.4 \%)$ in 1984 . The difference was almost significant $(p<0.05)$. The decreases from 1981 to 1982,1982 to 1983 , and 1983 to 1984 are, however, not significant $(p>0.462)$. The age group at risk for $C$ trachomatis coincided with that for $N$ gonorrhoeae, a result that is in agreement with that of other investigators. ${ }^{16-18} 2327$

Of interest is the fact that the yearly incidence of genital $C$ trachomatis infection did not decrease in our area during this period. In fact, diagnosed cases increased steadily during these years (to be published). In this respect the situation is opposite to that of gonorrhoea and acute salpingitis which decreased simultaneously. One of the reasons for this might be the use of oral contraceptive pills which have been shown to protect from ascending $C$ trachomatis infections. ${ }^{619-21}$ It has also been shown that acute salpingitis associated to $C$ trachomatis infection is clinically milder than that associated to $N$ gonorrhoeae. ${ }^{15} 17$ These facts may suggest that more patients with acute salpingitis were treated as out-patients in the study period of 1980-1984.

In conclusion, this study shows that there were fewer patients hospitalised for acute salpingitis in the early 1980 s compared with the early 1970 s. Gonorrhoea decreased significantly during both periods and there were significantly less patients with gonorrhoea and salpingitis in 1980-1984. Whereas gonorrhoea at present is of minor importance $C$ trachomatis is now the most frequently isolated specific agent in acute salpingitis. The use of IUCD is a significant factor for the development of acute salpingitis regardless of specific or non specific concomitant genital infection. At least in the district of Örebro in Sweden there are at present relatively more patients with acute salpingitis of unknown aetiology than in the early 1970 s.

Address for correspondence: Dr F Kamwendo, Department of Obstetrics and Gynaecology, Örebro Medical Centre, S-701 85 Örebro, Sweden

1 Falk V. Treatment of acute non-tuberculous salpingitis alone and in combination with glucocorticoids. Acta Obst Gynecol Scand 1965;44:Suppl 6,1-118.

2 Weström L, Isoif S, Svensson L, Märdh P-A. Infertility after acute salpingitis: Results of treatment with different antibiotics. Curr Ther Res 1979;26:752-9.

3 Weström L, Bengtsson L Ph, Márdh P-A. Incidence trends, and risks of ectopic pregnancy in a population of women. $\mathrm{Br} \mathrm{Med} \mathrm{J}$ $1981 ; 282: 15-18$.

4 Gisslén $H$, Hellgren $L$, Starck V. Incidence, age distribution and complications of gonorrhoea in Sweden. Bull WHO 1961;24: 367-74.
5 Rees E, Annels EH. Gonococcal salpingitis. $\mathrm{Br} J$ Venereal Dis 1969;45:205-15.

6 Eschenbach DA, Harnisch JP, Holmes KK. Pathogenesis of acute pelvic inflammatory disease: Role of contraception and other risk factors. Am J Obstet Gynecol 1977;128:838-50.

7 Thompson SE, Hager WD, Wong K-H, et al. The microbiology and therapy of acute pelvic inflammatory disease in hospitalised patients. Am J Obstet Gynecol 1980;136:179-85.

8 Grech ES, Everett JV, Mukasa F. Epidemiological aspects of acute pelvic inflammatory disease in Uganda. Trop Doct 1973; 3:123-7.

9 Brown IMCL, Cruicksank JG. Aetiological factors in pelvic inflammatory disease in urban blacks in Rhodesia. $S$ Afr Med $J$ 1976;50:1342-4.

10 Forslin L, Falk V, Danielsson D. Changes in the incidence of acute gonococcal and nongonococcal salpingitis. A five-year study from an urban area of central Sweden. Br J Venereal Dis 1978;54:247-50.

11 Jacobsson L, Weström L. Objectivised diagnosis of acute pelvic inflammatory disease. Am JObstet Gynecol 1969;105:1088-98.

12 Gästrin B, Kallings LO. Improved methods for gonococcal sampling and examination on a large scale. Acta Pathol Microbiol Scand 1968;74:362-70.

13 Danielsson D, Johannisson G. Culture diagnosis of gonorrhoea. Acta Dermato-venerol 1973;53:75-80.

14 Moi H, Danielsson D. Diagnosis of genital Chlamydia trachomatis infection in males by cell culture and antigen detection test. Eur J Clin Microbiol 1986;5:563-8.

15 Svensson L, Weström L, Ripa KT, et al. Differences in some clinical and laboratory parameters in acute salpingitis related to culture and serologic findings. Am J Obstet Gynecol 1980;138:1017-21.

16 Ripa KT, Svensson L, Treharne JD, Weström L, Märdh P-A. Chlamydia trachomatis infection in patients with laparoscopically verified acute salpingitis. Results of isolation and antibody determinations. Am J Obstet Gynecol (suppl) 1980;138:960-4.

17 Osser S, Persson K. Epidemiologic and serodiagnostic aspects of chlamydia salpingitis. Obstet Gynecol 1982;59:206-9.

18 Brihmer C, Kallings I, Nord C-E, et al. Salpingitis; aspects of diagnosis and epidemiology: a 4-year study from a Swedish capital hospital. Eur J Obstet Gynecol Reprod Biol 1987;24: 211-20.

19 Weström L. Incidence, prevalence and trends of acute pelvic inflammatory disease and its consequences in industralised countries. Am J Obstet Gynecol 1980;138:880-92.

20 Weström L, Bengtsson $\mathrm{L} \mathrm{Ph}$, Mårdh P-A. The risk of pelvic inflammatory disease in women using intrauterine contraceptive devices as compared to non-users. Lancet 1976;;ii:221-4.

21 Vessey M, Doll $R$, Peto $R$, et al. A long term follow-up study of women using different methods of contraception-An interim report. J Bioc Sci 1976;8:373-427.

22 Flesh G, Weiner JM, Corlett RC, et al. The intrauterine contraceptive device and acute salpingitis. Am J Obstet Gynecol 1979;135:402.

23 Osser S, Gullberg B, Liedholm P, et al. Risk of pelvic inflammatory disease among intrauterine device users irrespective of previous pregnancy. Lancet 1980;i:386.

24 National Central Bureau of Statistics. Women and childreninterviews with women about family and work. Forecasting Information 1982;4:33-41.

25 Nygren K-G, Odlind V. Anticonception. In: The National Cooperation of Swedish Pharmacists: Book of therapeutic drugs (Läkemedelsboken), Uppsala, Sweden: Almqvist \& Wiksell AB, 1985:976-89.

26 Fiscina B, Oster GK, Oster S, et al. Gonococcicidal action of copper in vitro. Am J Obstet Gynecol 1973;116:86-90.

27 Mảrdh P-A, Lind I, Svensson L, Weström L, Moller BR. Antibodies to Chlamydia trachomatis, Mycoplasma hominis and Neisseria gonorrhoeae in serum from patients with acute salpingitis. Br J Venereal Dis 1981;57:125-9.

Accepted 11 June 1990 